\title{
UPAYA MENINGKATKAN HASIL BELAJAR IPS EKONOMI DENGAN MENGGUNAKAN METODE INKUIRI PADA PESERTA DIDIK KELAS VIII SMP MUHAMMADIYAH PALANGKA RAYA
}

\author{
Oleh \\ Andi Admaja,* Bulkani** \\ Email:bulkani@ygmail.com
}

\begin{abstract}
This study aims to determine learning activities and increase learning outcomes. The subjects in this study were all students of class VIII.5 of Muhammadiyah Middle School in Palangka Raya, which numbered 23 students. The method in this study uses the Classroom Action Research (CAR) method. The results of the study show that: (1) Students are more active in the learning process, so that students can understand the material presented properly. This can be seen from the scores of social studies learning activities of students in the first cycle, there were 12 students who scored skor 21 and in the second cycle, there were 23 students who scored $\square 21$ : (2) the use of inquiry methods could improve learning outcomes. In the first cycle of 16 students, the average learning outcome was 61.30 with a percentage of $69.56 \%$ and in the second cycle of 23 students the average learning outcomes increased to 75.65 with a percentage of $95.65 \%$. There was an increase of $26.09 \%$ from cycle I to cycle II.
\end{abstract}

(C) Muhammadiyah University Palangkaraya

Keywords: Learning Outcomes, inquiry learning method on IPS

\section{ABSTRAK}

Penelitian ini bertujuan untuk mengetahui aktivitas belajar dan Peningkatan hasil belajar. Subjek dalam penelitian ini adalah seluruh peserta didik kelas VIII.5 SMP Muhammadiyah Palangka Raya yang berjumlah 23 orang peserta didik. Metode dalam penelitian ini menggunakan metode Penelitian Tindakan Kelas (PTK). Hasil penelitian menunjukkan bahwa: (1) Peserta didik lebih aktif dalam proses pembelajaran, sehingga peserta didik dapat memahami materi yang disampaikan dengan baik. Hal ini terlihat dari skor aktivitas belajar IPS peserta didik pada siklus I, terdapat 12 peserta didik yang memperoleh skor $\geq 21$ dan pada siklus II, terdapat 23 orang peserta didik yang memperoleh skor $\geq 21$ : (2) penggunaan metode inkuiri dapat meningkatkan hasil belajar. Pada siklus I dari 16 orang peserta didik, rata-rata hasil belajar adalah 61,30 dengan persentase $69,56 \%$ dan pada siklus II dari 23 orang peserta didik rata-rata hasil belajarnya meningkat menjadi 75,65 dengan persentase 95,65\%. Terdapat kenaikan sebanyak 26,09\% dari siklus I ke siklus II.

(C) Universitas Muhammadiyah Palangkaraya

Kata Kunci: Hasil Belajar, metode pembelajaran inkuiri pada IPS. 


\section{PENDAHULUAN}

Pendidikan mempunyai peranan yang sangat penting dalam kehidupan suatu bangsa. Pendidikan sebagai salah usaha mengembangkan sumber daya manusia yang memiliki kemampuan serta ikut bertanggung jawab atas penyiapan tenaga kerja terdidik dengan kualifikasi yang dapat diandalkan untuk menjamin prestasi dan kemampuan yang sepadan dengan tuntutan masa depan. Keunggulan daya saing sangat tergantung dari kualitas sumber daya manusia, dan hal itu tidak akan datang dengan sendirinya.

Menurut Slameto (2011:63) faktorfaktor yang mempengaruhi belajar adalah:

1. Metode mengajar, penggunaan metode yang kurang baik, akan mempengaruhi belajar peserta didik yang kurang baik pula. Guru yang lama biasa mengajar dengan metode ceramah, sehingga peserta didik menjadi bosan, mengantuk dan pasif. Guru yang progresif berani mencoba metode-metode yang baru, yang dapat meningkatkan kegiatan belajar mengajar.

2. Kurikulum, diartikan sebagai sejumlah kegiatan yang diberikan kepada peserta didik.

3. Relasi guru dengan peserta didik, didalam relasi yang baik, peserta didik akan menyukai gurunya, juga akan menyukai mata pelajaran yang diberikanya, sehingga peserta didik berusaha mempelajari sebaikbaiknya.

4. Pengertian orang tua, anak belajar perlu dorongan dan pengertian orang tua, bila anak sedang belajar jangan diganggu dengan tugas- tugas dirumah. Kadang anak mengalami lemah semangat, orang tua wajib memberi pengertian dan mendorongnya.

5. Latar belakang kebudayaan, tingkat pendidikan atau kebiasaan di dalam keluarga mempengaruhi sikap anak dalam belajar. Anak perlu ditanamkan kebiasaan-kebiasaan yang baik, agar mendorong anak untuk semangat belajar.

Menurut Daryanto (2010:11) hasil belajar adalah hasil yang dicapai peserta didik yang berupa kemampuan untuk mengerjakan soal-soal atau tes selama proses kegiatan belajar mengajar dalam periode tertentu yang dinyatakan dengan skor/nilai. Sedangkan menurut Oemar (Hamalik, 2009:30) hasil belajar adalah bila seseorang telah belajar akan terjadi perubahan tingkah laku pada orang tersebut misalnya dari yang tidak tahu menjadi tahu, dan tidak mengerti menjadi mengerti.

Hasil belajar ekonomi adalah hasil dari suatu interaksi belajar dan tindakan mengajar pelajaran ekonomi. Untuk guru, tindakan mengajar diakhiri dengan proses evaluasi hasil belajar. Sedangkan untuk peserta didik, hasil belajar merupakan puncak dari proses belajar yang merupakan suatu bukti dari usaha yang telah dilakukan.

Metode pembelajaran adalah caracara atau teknik penyajian bahan pelajaran yang akan digunakan oleh guru pada saat menyajikan bahan pelajaran, baik secara individual atau secara kelompok. Guru tidak harus selalu terpaku dengan satu metode, tetapi guru sebaiknya menggunakan 
beberapa metode yang bervariasi agar jalannya pengajaran tidak membosankan (Djamarah dan Zain, 2012:46).

Senjaya dalam Kokom Komalasari (2010:56) menyatakan bahwa metode adalah "a way in achieving something". Jadi metode pembelajaran sebagai cara yang digunakan untuk mengimplementasikan rencana yang sudah disusun dalam bentuk kegiatan nyata dan praktis untuk mencapai tujuan pembelajaran.

Menurut Wina Sanjaya (2006:194) Strategi pembelajaran inkuiri (SPI) adalah rangkaian pembelajaran yang menekankan kepada proses berfikir secara kritis dan analitis untuk mencari dan menemukan sendiri jawaban dari suatu masalah yang dipertanyakan. Proses berpikir itu sendiri biasanya dilakukan melalui tanya jawab antar guru dan peserta didik. Materi pelajaran tidak diberikan secara langsung. Peran peserta didik dalam strategi ini adalah mencari dan menemukan sendiri materi pelajaran, sedangkan guru berperan sebagai fasilitator dan pembimbing peserta didik untuk belajar.

Dalam metode ini peserta didik lebih banyak terlibat dalam kegiatan pembelajaran, sehingga peserta didik tidak hanya mendengarkan ceramah yang disampaikan oleh guru tetapi peserta didik lebih memiliki kesempatan untuk berpikir.

Dalam proses berpikir mereka, peserta didik dapat merumuskan jawaban dari masalah yang disajikan sehingga perkembangan kognitif tiaptiap individu peserta didik dapat terlaksana. Metode inkuiri dimaksudkan untuk merangsang keingintahuan peserta didik berdasarkan fakta-fakta yang ada dengan ajuan pertanyaanpertanyaan dari guru.

Dengan metode inkuiri ini, suasana pembelajaran didalam kelas menjadi lebih hidup agar metode inkuiri dapat terlaksana dengan baik, haruslah tercipta, kondisi belajar yang fleksibel dalam interaksi belajar. Kondisi lingkungan sedapat mungkin memancing gairah intelektual dan semangat belajar yang tinggi. Guru juga harus mampu menciptakan kondisi belajar yang kondusif dan responsif.

Pada dasarnya tujuan pendidikan IPS adalah untuk mendidik dan memberi bekal kemampuan dasar kepada peserta didik untuk mengembangkan diri sesuai dengan bakat, minat, kemampuan dan lingkunganya, serta berbagai bekal bagi peserta didik untuk melanjutkan pendidikan yang lebih tinggi (Etin Solihatin dan Raharjo, 2011:15).

Dalam kegiatan belajar mengajar IPS terlebih dahulu dijelaskan hubungan antara strategi, metode dan teknik pembelajaran. Suatu strategi mengajar mungkin menggunakan beberapa pendekatan dan dalam pendekatan mungkin terdapat lebih dari satu metode. Pemilihan dalam suatu metode mungkin dapat menggunakan lebih dari satu teknik mengajar.

Semua pendekatan, metode dan teknik pembelajaran dari suatu bahan pelajaran tergantung dari ciri khas bahan pelajaran, keadaan sarana dan keadaan peserta didik. Dalam pelaksanaan kegiatan belajar mengajar, 
guru memperhatikan azaz-azaz pengembangan kurikulum serta tujuan pengajaran IPS dikelas VIII SMP Muhammadiyah Palangka Raya.

Berdasarkan penjelasan di atas maka tujuan penelitian ini adalah:

1. Untuk mengetahui aktivitas belajar peserta didik pada pembelajaran ekonomi dengan menggunakan metode inkuiri di kelas $\quad$ VIII.5 SMP Muhammadiyah Palangkaraya.

2. Untuk mengetahui peningkatan hasil belajar peserta didik kelas VIII.5 pada pembelajaran ekonomi dengan menggunakan metode inkuiri di SMP Muhammadiyah Palangkaraya.

\section{METODOLOGI PENELITIAN}

Metode penelitian adalah suatu cara yang digunakan peneliti untuk melakukan penelitian. Dalam penelitian ini, peneliti menggunakan model Penelitian Tindakan Kelas (PTK) dengan dua siklus, yang direncanakan dan didefinisikan sebagai suatu bentuk penelitian yang bersifat refleksi dengan melakukan tindakan-tindakan tertentu untuk memperbaiki dan meningkatkan praktik pembelajaran di kelas agar lebih baik.

Kunandar

(2012:46), mengemukakan bahwa Penelitian Tindakan Kelas adalah suatu kegiatan ilmuan yang dilakukan oleh guru di kelasnya sendiri dengan jalan merancang, melaksanakan, mengamati dan merefleksikan tindakan melalui beberapa siklus secara kolaboratif dan partisipatif yang bertujuan untuk memperbaiki atau meningkatkan mutu proses pembelajaran di kelasnya.

Dari pendapat di atas dapat disimpulkan bahwa Penelitian Tindakan Kelas adalah penelitian yang dilakukan guru secara sistematis dalam kegiatan belajar berupa sebuah tindakan dalam sebuah kelas secara bersama melalui refleksi diri untuk meningkatkan hasil belajar peserta didik.

\section{HASIL PEMBAHASAN}

Pra tindakan adalah perlakuan awal seorang guru kepada peserta didik sebelum memasuki materi yang diajarkan. Dalam melakukan pra tindakan guru harus melakukan observasi dan tes pra tindakan. Sehingga dapat dijadikan sebagai tolak ukur keberhasilan pembelajaran, selanjutnya kedua data tersebut disajikan dalam pendeskripsian sebagai berikut:

Tes pra tindakan dalam penelitian ini yaitu bertujuan untuk mengetahui tingkat pemahaman peserta didik terhadap materi yang akan dijadikan topik pembelajaran sebelum penelitian tindakan kelas dilaksanakan. Tes yang dilakukan dalam penelitian ini dilaksanakan dengan memberikan pelajaran tanpa menggunakan Metode Pembelajaran Inkuiri, kemudian peserta didik mengerjakan soal berupa pilihan ganda yang berjumlah 20 (dua puluh) butir soal.

Adapun berdasarkan tindakan penelitian yang dilakukan sebanyak 2 siklus, hasil observasi keaktifan peserta didik yang dilihat dari lembar observasi setiap siklus diperoleh skor sebagai berikut: 


\section{Tabel 14 \\ Hasil Observasi Aktivitas Peserta Didik}

Berdasarkan tabel di atas maka dapat diuraikan bahwa skor aktivitas belajar peserta didik pada siklus I secara individual terdapat 12 orang peserta didik yang mendapat skor $\geq 21$ dan 11 orang peserta didik yang mendapat skor di bawah 21 dengan skor rata-rata 18,52. Sehingga aktivitas peserta didik pada siklus I belum bisa dikatakan baik.

Skor aktivitas belajar peserta didik pada siklus II secara individual terdapat 22 orang peserta didik yang mendapat skor $\geq 21$ dan 1 orang peserta didik yang mendapat skor di bawah 21 dengan skor rata-rata 22,86. Sehingga aktivitas peserta didik pada siklus II sudah dapat dikatakan baik.

Berdasarkan tabel di atas maka dapat diketahui bahwa hasil belajar peserta didik dari tes awal (pre test) sampai dengan siklus II telah mengalami peningkatan, dari 14 peserta didik pada tes awal jumlah peserta didik yang tuntas adalah 2 orang, siklus I ada 16 orang peserta didik yang tuntas, dan pada siklus II ada 19 orang peserta didik yang tuntas. Jumlah peserta didik yang tidak tuntas pada tes awal (pre test) ada 21 orang peserta didik, siklus I ada 7 orang peserta didik dan siklus II ada 2 orang peserta didik. Berikut grafik peningkatan hasil

belajar peserta didik dari tes awal sampai siklus II:

Berdasarkan rumusan masalah dan indikator kinerja yang ditentukan dalam penelitian ini, sesuai dengan data temuan hasil analisis keaktifan dan peningkatan hasil belajar peserta didik setelah dilakukan perbaikan dengan menggunakan metode pembelajaran

\begin{tabular}{|c|c|c|}
\hline Siklus & $\begin{array}{c}\text { Rata- } \\
\text { Rata }\end{array}$ & $\begin{array}{c}\text { Jumlah Peserta Didik } \\
\text { yang memperoleh skor } \geq \\
\text { 21 }\end{array}$ \\
\hline Siklus I & 18,52 & 12 Peserta Didik \\
\hline Siklus II & 22,86 & 22 Peserta Didik \\
\hline
\end{tabular}

inkuiri terbukti dapat mencapai hasil yang lebih baik dari sebelumnya. Pada pelaksanaan peningkatan hasil belajar peserta didik dalam pembelajaran IPS ini terbukti telah terjadinya peningkatan dari kondisi awal yang 8,7\% (2 orang) yang tuntas, menjadi $95,65 \%$ (22 orang) peserta didik yang tuntas..

\section{KESIMPULAN}

Aktivitas peserta didik dalam belajar IPS dengan menggunakan metode pembelajaran inkuiri pada kelas VIII.5 SMP Muhammadiyah Palangkaraya. Pada siklus I terdapat 12 orang peserta didik yang memperoleh skor $\geq 21$ dan pada siklus II terdapat 22 orang peserta didik yang memperoleh skor $\geq 21$. Peserta didik lebih aktif dalam proses pembelajaran, sehingga peserta didik dapat memahami materi yang disampaikan dengan baik.

Ada peningkatan hasil belajar IPS setelah menggunakan metode pembelajaran inkuiri pada kelas VIII.5 SMP Muhammadiyah Palangkaraya. Pada pre-test dapat diketahui perolehan hasil persentase $8,7 \%$ (2 orang) peserta didik yang tuntas dan peserta didik yang tidak tuntas 91,3\% (21 orang) dengan nilai rata-rata 37. Adapun perolehan hasil pada siklus I jumlah persentase 
hasil belajar peserta didik mencapai 69,56\% (16 orang) peserta didik yang tuntas dan 30,44\% (7 orang) peserta didik yang tidak tuntas dengan rata-rata 61,30. Pada siklus II, perolehan hasil belajar peserta didik adalah 95,65\% (22 orang yang tuntas dan $4.35 \%$ (1 orang) yang tidak tuntas dengan ratarata $75,65 \%$. Ada peningkatan hasil belajar IPS dari pre test ke siklus I yaitu sebanyak 60,86\%, sedangkan dari siklus I ke siklus II ada peningkatan hasil belajar yaitu sebanyak 26,09\%. Ini dapat disimpulkan bahwa ada peningkatan hasil belajar dengan menggunakan metode pembelajaran inkuiri pada kelas VIII.5 SMP Muhammadiyah Palangkaraya.

DAFTAR PUSTAKA

Daryanto. 2010. Pengertian belajar. Diakses http://misterchand89.blogspot.co.i d

Djamarah dan Zain. (2012). Strategi Belajar Mengajar. Jakarta: Rineka Cipta.

Hamalik, Oemar., (2009), Perencanaan Pengajaran Berdasarkan Sistem, Jakarta: Pustaka Belajar.

Komalasari, Kokom. 2010. Pembelajaran kontekstual: Konsep dan Aplikasi. Bandung: PT Refika Aditama.

Kunandar, (2012), Langkah Mudah Penelitian Tindakan Kelas Sebagai Pengembangan Profesi Guru, Jakarta : PT Raja Granpindo Persada.

Slameto. 2011. Belajar dan FaktorFaktor yang Menpengaruhinya. Jakarta: PT Rineka Cipta.

Wina Sanjaya. 2006. Strategi Pembelajaran Beriroentasi Standar proses Pendidikan. Jakarta: Kencana Prenada Media 